\title{
Prilog II. \\ Izložba: Vladan Desnica i Desničini susreti \\ Gradska knjižnica Zadar, 18. - 28. rujna 2013.
}

\section{Ivana Cvijović Javorina}

UDK : 929Desnica, V.:021.4(497.5 Zadar)"2013"

Sažetak: U tekstu se daje kratak prikaz izložbe posvećene Vladanu Desnici i Desničinim susretima, održane u Gradskoj knjižnici Zadar od 18. do 28. rujna 2013. godine u sklopu međunarodnoga znanstvenog skupa Desničini susreti 2013.: Intelektualac danas. Izložba je bila podijeljena u četiri tematske cjeline: 1. Zadranin Vladan Desnica, 2. Islamljanin Vladan Desnica, 3. Kula Jankovića u Islamu Grčkom: vitalnost baštine i 4. Desničini susreti: jučer, danas i sutra. Prvi cilj izložbe bilo je razvijanje svijesti zadarskih posjetitelja o Vladanu Desnici kao njihovu sugrađaninu i kao baštiniku kulturnog dobra u zadarskoj okolici. Drugi cilj bila je popularizacija Desničinih susreta. Autori izložbe nisu željeli samo obavijestiti posjetitelje o dosadašnjim djelatnostima Desničinih susreta, već i pobuditi njihov interes za aktivniji odnos prema tom programu. Također su na pregledan način dali podatke o tome što je sve učinjeno na obnovi Kule Jankovića u Islamu Grčkom, prije svega podrškom i financijskom potporom Ministarstva kulture Republike Hrvatske. Upoznali su posjetitelje is planovima njezine revitalizacije, posebno s projektom Međunarodnoga sveučilišnog centra.

Ključne riječi: izložba, Vladan Desnica, Desničini susreti, Kula Stojana Jankovića, Islam Grčki, Zadar

Tijekom sudjelovanja u manifestaciji Zadar čita Gradske knjižnice Zadar u travnju 2013. godine Veljku Barbieriju postavljeno je pitanje na koje je taj poznati hrvatski književnik i gastronomski stručnjak dao za slušatelje neočekivani odgovor. Bez imalo oklijevanja odgovorio je da je Vladan Desnica pisac od kojega je najviše naučio. Iako mnogi u Zadru znaju da su glavni protagonisti Desničina romana Zimsko ljetovanje izbjeglice iz bombardiranog Zadra i da je radnja smještena u Zadar i zadarsko zaleđe 1943. i 1944. godine, malobrojni su oni koji znaju da je Vladan Desnica rođen u tom gradu, a još malobrojniji koji ga doživljavaju kao Zadranina.

Saznavši za ovu zgodu tijekom radnog posjeta Gradskoj knjižnici Zadar i razgovora s njezinim ravnateljem Ivanom Peharom i višim knjižničarom Mladenom Masarom 17. travnja 2014. godine, prof. dr. sc. Drago Roksandić i ja uvjerili smo se da je naš ranije izneseni pismeni prijedlog o organizaciji izložbe u Gradskoj knjižnici Zadar o Vladanu Desnici i Desničinim susretima naišao na plodno tlo. Izložbu smo odlučili prirediti u Zadru, gradu domaćinu Desničinih susreta 2010., 2012. i 2013. godine, razmišljajući o tome kako Susrete približiti Zadranima, a imajući na umu tek povremenu percepciju Vladana Desnice kao njihova sugrađanina i jednoga od najvećih zadarskih pisaca. 


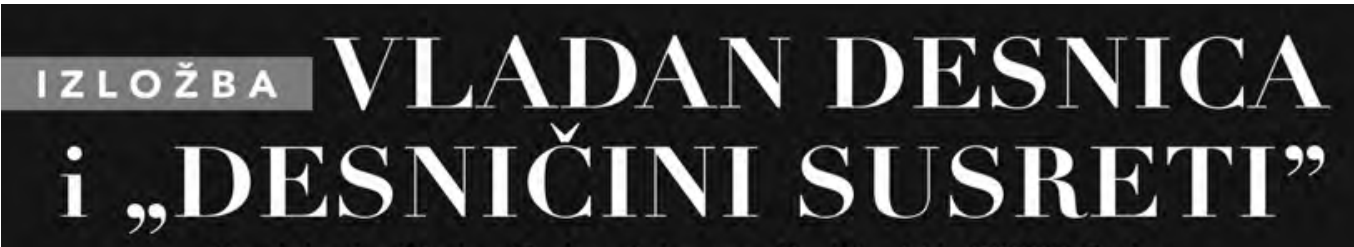

Gradska knjižnica Zadar; Sıjepana Radića IIb, 23000 Zadar

18. 28. rujna 2013.

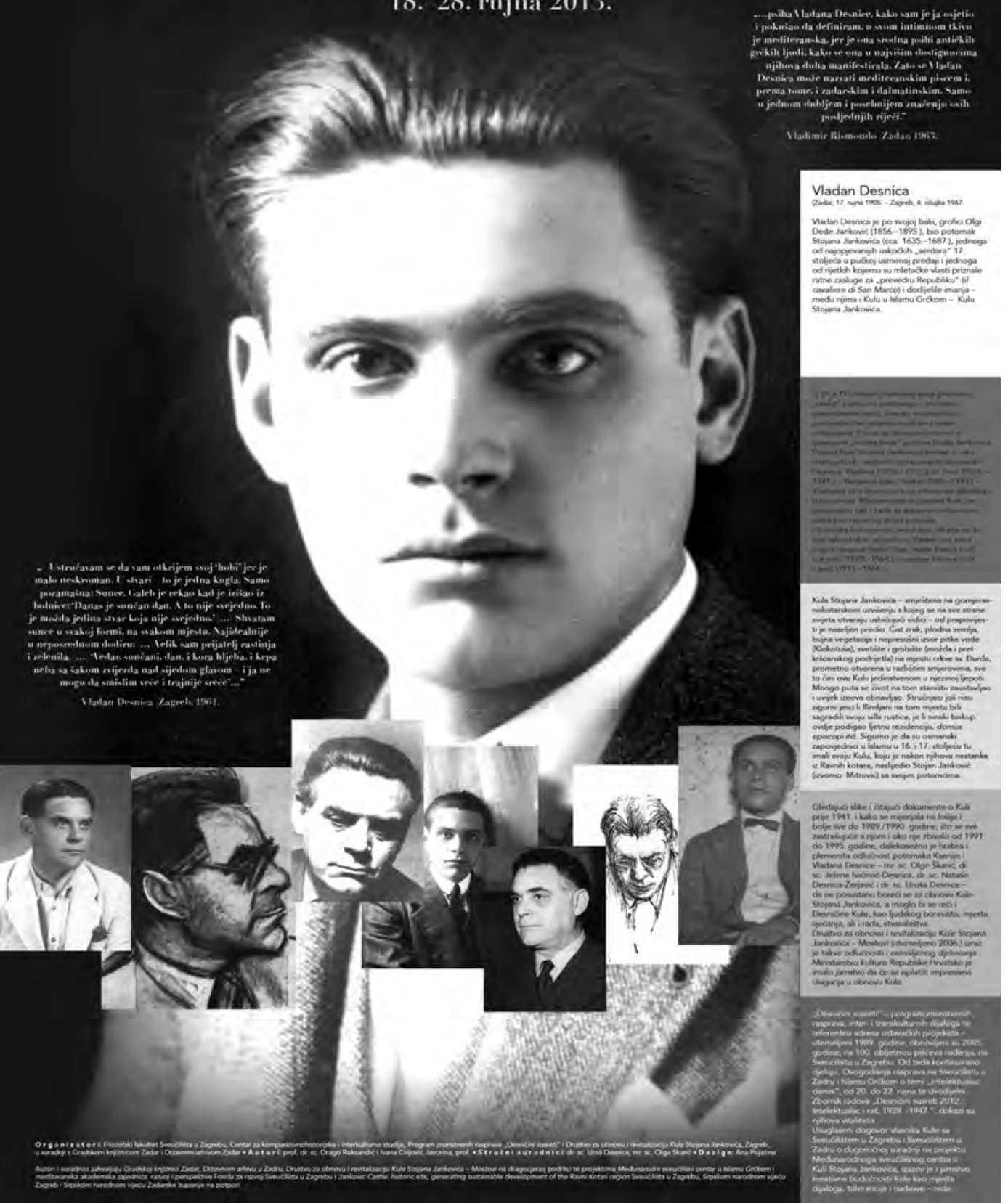

Sl. 3. Naslovni plakat izložbe održane u Gradskoj knjižnici Zadar, 18. - 28. rujna 2013.

Design: Ana Pojatina 


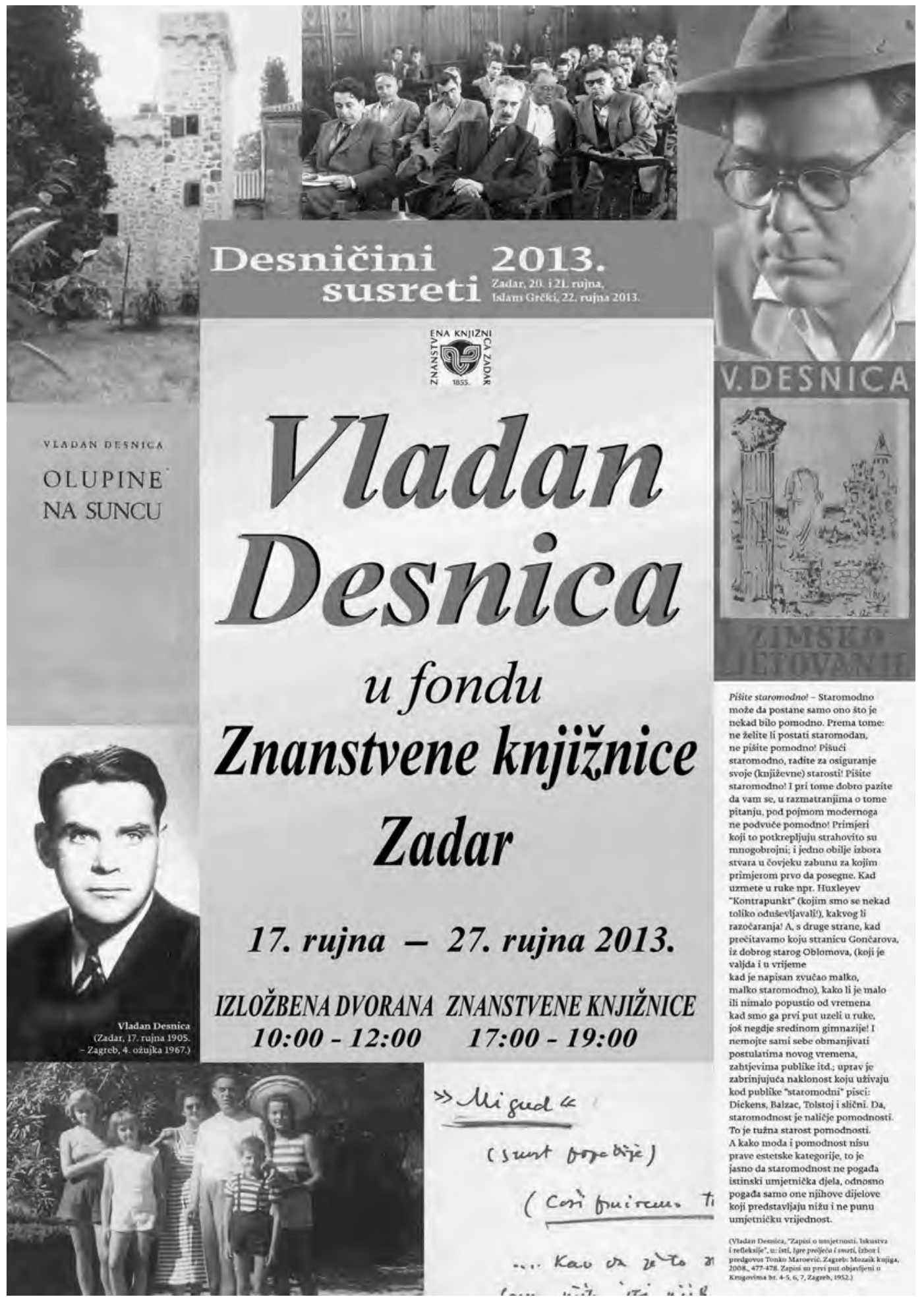

Sl. 4. Naslovni plakat izložbe održane u Znanstvenoj knjižnici Zadar, 17. - 27. rujna 2013.

Design: Dejan Dragosavac Ruta 
Svoj smo prijedlog iznijeli Gradskoj knjižnici Zadar i Muzeju grada Zadra, a potom i - slijedom događaja - Znanstvenoj knjižnici Zadar i Državnom arhivu u Zadru. Izložba pod radnim naslovom "Vladan Desnica i Desničini susreti" i podnaslovom "Povodom 25. obljetnice Desničinih susreta" trebala je prema našemu prijedlogu obuhvatiti četiri cjeline s provizornim naslovima "Zadranin Vladan Desnica", "Islamljanin Vladan Desnica", "Stvaralaštvo Vladana Desnice u zadarskim knjižnicama" i "Desničini susreti: jučer, danas i sutra”. Na naše veliko zadovoljstvo Ivan Pehar prihvatio je da domaćin izložbe bude Gradska knjižnica Zadar. Moguće je da je jedan od glavnih argumenata u prilog našemu prijedlogu bila tada recentna anegdota o izjavi Veljka Barbierija i reakciji slušateljstva.

Ako se program Desničinih susreta i nije u cijelosti svake godine održavao na Sveučilištu u Zadru, od 2006. godine svake je godine završavao u Desničinoj Kuli Stojana Jankovića u Islamu Grčkom, u neposrednoj blizini Zadra. Ipak, njihov rad nije privlačio posebnu pozornost Zadrana. Kako je za upućene stručnjake neupitno da je Vladan Desnica jedan od najvećih pisaca u zadarskoj povijesti - pitanje je bilo kako Zadrane podsjetiti na njega, odnosno kako im ga približiti. Jedna od ideja bila je izložiti na frekventnome mjestu prije svega vizualno atraktivne materijale u vezi s književnikom Vladanom Desnicom kao zadarskim sugrađaninom i kao baštinikom kulturnog dobra u zadarskoj okolici.

Ideja je bila i popularizirati njegov književni opus dostupan u zadarskim knjižnicama, odnosno potaknuti brojnu zadarsku čitateljsku publiku da ga čita. Ova potonja ideja odvela nas je u Znanstvenu knjižnicu Zadar. Tijekom razgovora s ravnateljem Znanstvene knjižnice mr. sc. Mirom Grubićem otvorila se mogućnost organizacije izložbe koja će skrenuti pozornost na sva Desničina djela dostupna u knjižničnom fondu i upoznati posjetitelje kako se i kada sve na to medijski reagiralo. Složili smo se da bi iz organizacijskih razloga bilo vrlo teško osigurati transport vrijednih izdanja Desničinih djela na bilo koju drugu lokaciju u gradu. Stoga smo spremno prihvatili njegov prijedlog da Znanstvena knjižnica u potpunosti preuzme na sebe organizaciju predstavljanja Desničinih djela u zadarskim knjižnicama i da se organiziraju dvije paralelne izložbe. Ta druga izložba održana je u Znanstvenoj knjižnici Zadar od 17. do 27. rujna 2013. uz pomoć obitelji Desnica, piščevih nasljednika. Oni su posudili knjižnici neka Desničina tiskana djela i autografe. Također su ustupili i audio snimku intervjua Vladana Desnice koja se reproducirala tijekom razgledavanja izložbe. Vrijedi dodati da je taj intervju jedini sačuvani zapis njegova glasa.

Spremnost na suradnju izrazio je i Ante Gverić, ravnatelj Državnog arhiva u Zadru, omogućivši nam korištenje i reprodukciju arhivalija potrebnih za kompletiranje određenih izložbenih cjelina. Zbog kratkoga vremenskog roka i administrativnih poteškoća nismo, nažalost, uspjeli realizirati suradnju s Muzejom grada Zadra. Namjera nam je bila osigurati reprodukcije suvremenih fotografija Zadra, katastarskih izvadaka zadarske kuće nekoć u posjedu Desnica, obitelji u kojoj je rođen Vladan Desnica, kao i profesionalno snimanje garniture namještaja koju je on prodao muzeju, a koja je danas jedan od impresivnijih izložaka pohranjenih u muzeju (iako se na legendi ne navodi njezino porijeklo).

Osim navedenih postojao je još jedan vrlo važan razlog za našu inicijativu o izložbi. Početkom 2013. godine, pripremajući knjigu Vladan Desnica i Desničini susreti: Pogled unatrag, pogled unaprijed, jednu u nizu zajedničkih suuredničkih publikacija, prof. dr. sc. Drago Roksandić i ja postali smo svjesni činjenice da se te godine obilježava 25. obljetni- 
ca utemeljenja Desničinih susreta. ${ }^{4}$ Zaključili smo stoga da su Desničini susreti 2013. pravo vrijeme i mjesto za iskorak u druge oblike njihove medijalne prezentacije. Ideja je bila i popularizirati Desničine susrete. Namjera nam nije bila samo obavijestiti posjetitelje o njihovim djelatnostima, već i pobuditi njihov interes za aktivniji odnos prema tom programu.

Htjeli smo i informirati Zadrane što je sve učinjeno, prije svega podrškom i financijskom potporom Ministarstva kulture Republike Hrvatske, na obnovi Kule Jankovića u Islamu Grčkom i kakvi sve planovi postoje za njezinu revitalizaciju, posebno kada je riječ o zagrebačko-zadarskom Međunarodnom sveučilišnom centru. Naposljetku, cilj je bio poručiti građanima Zadra da se njegov urbani dinamizam održava i na jednome od onih područja u gradskoj okolici koja su bila najteže pogođena Domovinskim ratom te da na svoju "mentalnu kartu" trebaju upisati i Vladana Desnicu i Kulu Stojana Jankovića u Islamu Grčkom kao kreativne agense zadarskog razvoja, kako kulturnog tako i gospodarskog.

Izložba je održana od 18. do 28. rujna 2013. u Gradskoj knjižnici Zadar u organizaciji Centra za komparativnohistorijske i interkulturne studije Filozofskog fakulteta Sveučilišsta u Zagrebu - Programa društveno-humanističkih i kulturoloških rasprava Desničini susreti i Društva za obnovu i revitalizaciju Kule Stojana Jankovića - Mostovi, u suradnji s Gradskom knjižnicom Zadar i Državnim arhivom Zadar. Autori izložbe bili su prof. dr. sc. Drago Roksandić i doktorandica Ivana Cvijović Javorina, stručni suradnici dr. sc. Uroš Desnica i mr. sc. Olga Škarić, a izložbene panoe dizajnirala je Ana Pojatina.

Autori i suradnici i ovom prilikom zahvaljuju Gradskoj knjižnici Zadar, Državnom arhivu u Zadru i Društvu za obnovu i revitalizaciju Kule Stojana Jankovića - Mostovi na dragocjenoj podršci te projektima Međunarodni sveučilišni centar u Islamu Grčkom i mediteranska akademska zajednica Fonda za razvoj Sveučilišta u Zagrebu i Jankovic Castle: historic site, generating sustainable development of the Ravni Kotari region Sveučilišta u Zagrebu, Srpskom narodnom vijeću Zagreb i Srpskom narodnom vijeću Zadarske županije na financijskoj potpori.

Cilj je ovoga priloga, pored ostalog, da bude dokumentarni zapis o prvoj izložbi ove vrste posvećenoj Vladanu Desnici i njegovoj Kuli Stojana Jankovića.

I. Zadranin Vladan Desnica. U prvoj cjelini pokušali smo smjestiti Vladana Desnicu u zadarski kontekst. Njegov otac dr. Uroš (1874. - 1941.) bio je poznati zadarski odvjetnik, bečki doktor prava, aktivan i u političkom životu kao jedan od aktera $\mathrm{Hr}$ vatsko-srpske koalicije u Dalmaciji i jedan od čelnih ljudi zadarskoga Narodnog vijeća. Imao je velike zasluge i za zadarsku politiku i kulturu jer je na prijelazu 1919./1920. u neizvjesnoj situaciji u okupiranom Zadru pokrenuo Naš list, zadarsko glasilo na hrvatskom jeziku. S nekoliko smo fotografija pokušali predočiti vrlo kultivirano okruženje u kojemu su odrasli Vladan Desnica i njegova sestra Nataša (1907. - 1996.), s kojom je čitav život bio posebno blizak. Kao djeca iz imućne obitelji imali su kućnog učitelja u Zadru, Šimu Šestana, o kojemu zasad nije poznato previše detalja. Već su zarana dobivali poduku iz glazbe, a Vladan Desnica je sve do Drugoga svjetskog rata dvojio treba li svoju stvaralačku energiju posvetiti književnosti ili glazbi. Fotografijom osmogodišnjega Vladana Desnice iz Venecije simbolično smo nastojali evocirati njegov kasniji odnos prema talijanskoj kulturi, kojoj je ostao posebno privržen sve do kraja života i u kojoj je

Drago Roksandić - Ivana Cvijović Javorina (ur.), Vladan Desnica i Desničini susreti: Pogled unatrag, pogled unaprijed, Zagreb 2013. 


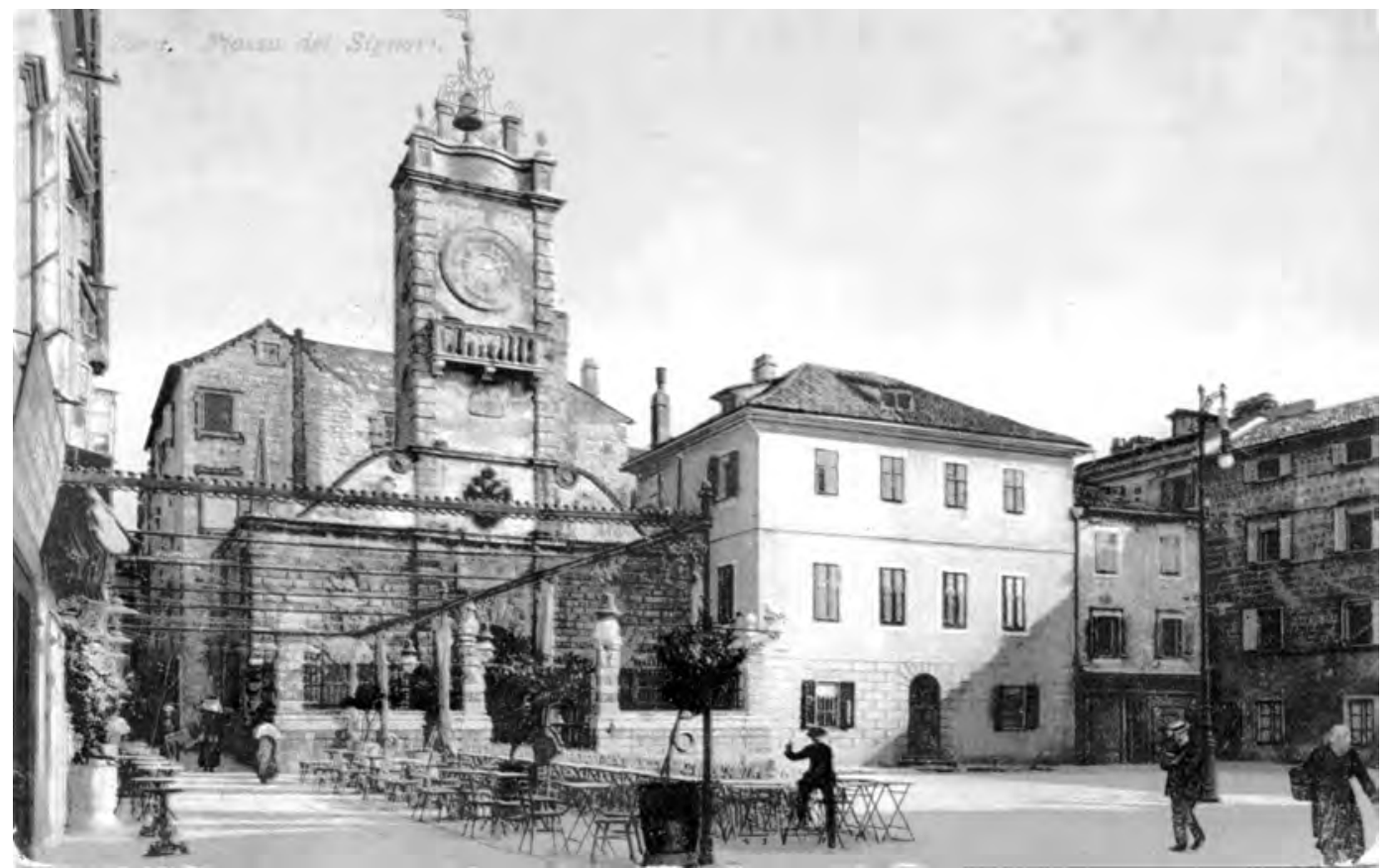

Sl. 5. Rodna kuća književnika Vladana Desnice (Zadar, 17. rujna 1905. - Zagreb, 4. ožujka 1967.) nalazi se $s$ lijeve strane Narodnog trga (Piazza dei Signori). Na razglednici se ispred nje nalazi kavana. Peterosobni stan zadarskog odvjetnika dr. Uroša Desnice i njegove supruge Fanny Desnica (rođ. Luković) nalazio se na prvome katu. U njemu su s troje djece - Olgom (1901. - 1911.), Vladanom i Natašom (1907. - 1996.) živjeli do 1920. godine, kada su morali napustiti Zadar.

nalazio brojne uzore, poput, primjerice, Benedetta Crocea, bez kojih nije moguće razumjeti njegov opus. Uzor i neosporni autoritet koji je utjecao na oblikovanje ličnosti Vladana Desnice bio je zasigurno i njegov djed s očeve strane Vladimir (1850. - 1922.), po kojemu je i dobio ime. On je također bio ugledni Zadranin i jedan od važnijih aktera u hrvatsko-srpskoj suradnji nakon 1905. godine. Početkom Prvoga svjetskog rata nestalo je idiličnog djetinjstva Vladana i Nataše. Djed Vladimir, otac Uroš i stric Boško bili su za austro-ugarske vlasti "veleizdajnici" i morali su biti što manje uočljivi. Vladan je započeo svoje zadarsko gimnazijsko školovanje u uvjetima koji nisu bili najpoticajniji. $\mathrm{O}$ tome rječito svjedoče ocjene sa svjedodžbe zadarske gimnazije, koja je također bila reproducirana na izložbi. Naravno, postavlja se pitanje bi li Vladan Desnica bio odličan učenik i u predratnim uvjetima. Vrlo je rano u svojoj imaginaciji stvorio vlastiti, artistički svijet, u kojemu su najvažnija bila literarna i glazbena mjerila.

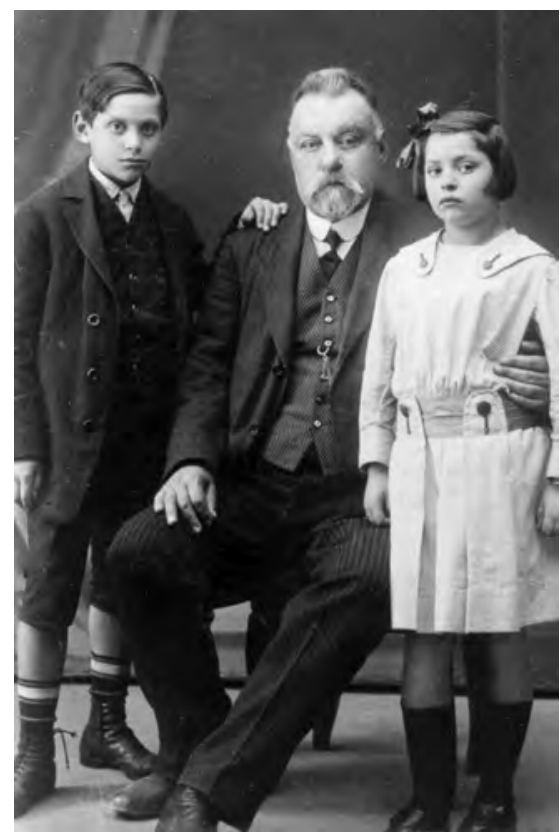

Sl. 6. Nataša i Vladan Desnica s djedom Vladimirom oko 1915. godine u Zadru. Foto: Valentino Ceregato, Zadar 


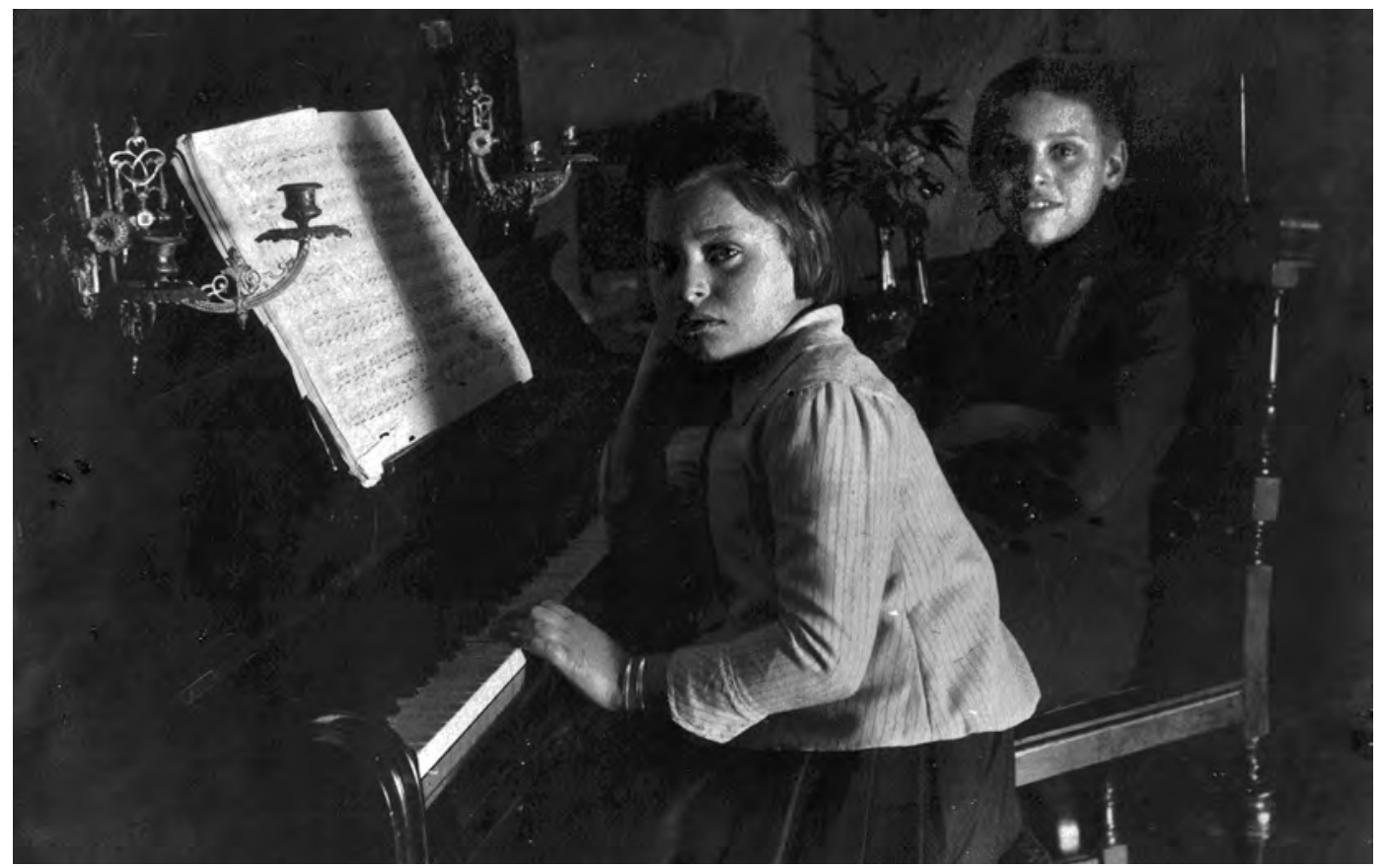

Sl. 7. Nataša i Vladan Desnica za klavirom u zadarskom stanu oko 1916. godine

Godine 1920. obitelj Desnica bila je prisiljena po minimalnim cijenama rasprodati sve što je u Zadru imala i preseliti se u zavičajni Obrovac. Nakon života u Splitu u međuratnim godinama Vladan Desnica ponovno se vratio u Zadar 1942. godine, ali je 1943. otišao na svoj posjed u Kulu Stojana Jankovića u Islamu Grčkom. Drugi dio prve cjeline bio je posvećen njegovu životu u Zadru nakon 1942. godine i prikazao je neke od težih trenutaka koje je proživio. Jedan od dojmljivijih svakako je bio gubitak kovčega s najvažnijim književnim rukopisima na putovanju brodom iz Splita preko Šibenika za Zadar, dokumentiran u dirljivu pismu sestri Nataši u srpnju 1942. godine. Dio je bio posvećen i romanu Zimsko ljetovanje, koji je predan nakladniku u ljeto 1949. godine, a tiskan 1950. godine. Taj je roman autora preko noći pretvorio u jednoga od najkontroverznijih pisaca u Hrvatskoj, pa i Jugoslaviji. Postao je "angažirani intelektualac”. Jedino glasilo koje je prihvatilo objaviti Desničine odgovore "partijskim kritičarima” ovog romana bila je Zadarska revija.

II. Islamljanin Vladan Desnica. "Dakle, iz Islama najviše su mi ipak pejzaži ostali, pejzaži najviše odjeka imaju, ja mislim, u mojim knjigama. A kućâ, znate, u mnogim sam kućama živio, i gradskim, i na selu, na imanju, i u raznim gradovima i tako dalje, pa se sve to miješa, osobito ono iz djetinjstva. Pojedini detalj se uzme odavde i odande. Pejzaža mnogo ima iz Islama. Pejzaža i štimunga u mojim djelima." ${ }^{5}$ Riječi su to Vladana Desnice iz jednog intervjua koje potvrđuju da je u proučavanju književnog stvaralaštva Vladana Desnice nemoguće zaobići utjecaj koji je na njega ostavio Islam Grčki. Utjecali su na njega zasigurno i Zadar i drugi dijelovi Ravnih kotara.

5 "Razgovor s Vladanom Desnicom o unjetničkom stvaranju”, u: Vladan DesnicA, Hotimično iskustvo: diskurzivna proza Vladana Desnice. Knjiga druga (prir. Dušan Marinković), Zagreb 2006., 121. 


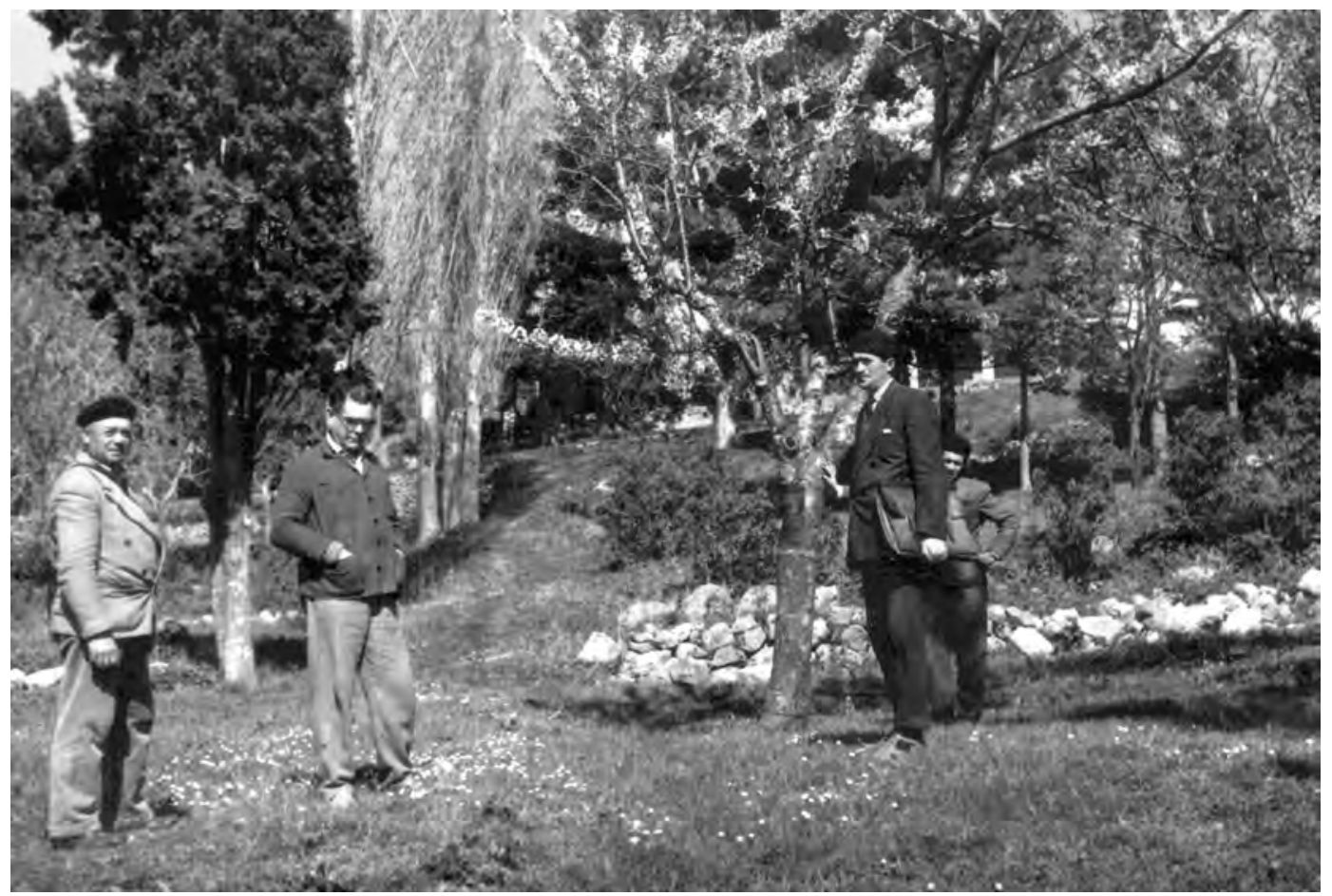

Sl. 8. Vladan Desnica s danas nepoznatim gostima u parku Kule Stojana Jankovića sredinom 1950-ih

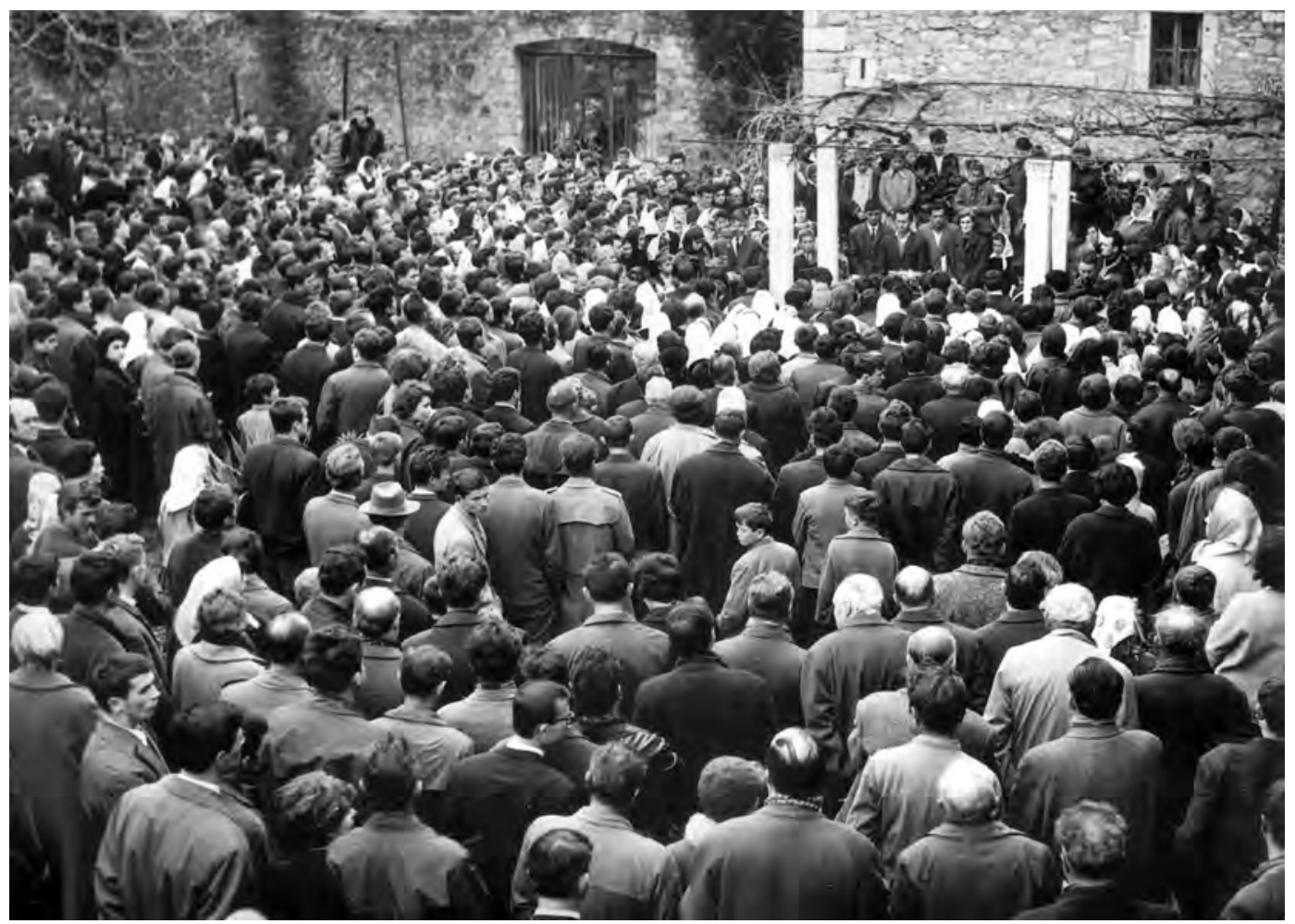

Sl. 9. Sahrana Vladana Desnice u crkvi sv. Đurđa pored Kule Stojana Jankovića. Foto: Brkan, Zadar 
Razmišljajući o tome kako dočarati ambijent u koji se Vladan Desnica sklonio s obitelji 1943. godine i koji će naposljetku postati njegovo posljednje počivalište, odlučili smo se na kontrastiranje fotografija interijera i eksterijera Kule $s$ fotografijama obitelji, prijatelja i drugih ljudi s kojima se tamo susretao. Uz fotografiju balkona radne sobe Vladana Desnice, na njegovo književno stvaralaštvo neizravno upućuje i fotografija "Peškijere", odnosno akumulacijskog bazena, kao podsjetnik na često javljanje motiva vode u njegovim književnim djelima.

Reproducirano je i nekoliko autografa Vladana Desnice, djela koja su nastala tijekom njegova boravka u Kuli, uključujući i fragment iz Zimskog ljetovanja. Kao i još nekoliko njegovih književnih radova, roman je nastajao u Zagrebu i Islamu Grčkom između 1945. i 1949. godine, u intermezzima između Desničinih radnih dužnosti šefa pravne službe Ministarstva financija NR Hrvatske u Zagrebu i brojnih obiteljskih briga u poratnom Zagrebu, Islamu i Splitu. Dio fotografija, uključujući i fotografije s književnikove sahrane 1967. godine, snimio je poznati zadarski fotografski studio Brkan.

III. Kula Jankovića u Islamu Grčkom: vitalnost baštine. U trećoj smo cjelini istaknuli neke od prepoznatljivijih simbola lokaliteta aktivnoga od prapovijesti do suvremenog doba. Kontinuitet kulturnih diskontinuiteta ili stalnost nerijetko međusobno isključivih kulturnih obrazaca i praksi u tako dugom vremenu čine Kulu i tipičnim i iznimnim lokalitetom u kulturnoj baštini Zadarske županije. Teško je stradala u Domovinskom ratu. Da tragedija bude još veća, dogodilo se to svega nekoliko godina nakon velikih konzervatorskih radova krajem osamdesetih godina. Tim su veći sinergijski učinci svega što je učinjeno nakon 2000. godine, prije svega naporima obitelji Desnica, Ministarstva kulture Republike Hrvatske te Sveučilišta u Zagrebu i Sveučilišta u Zadru. Konačni je cilj da postupno obnavljana Kula postane polivalentni kulturni centar u lokalnim, ali u konačnici i svjetskim razmjerima kao središte Međunarodnoga sveučilišnog centra.

Desničini susreti, utemeljeni 1989. godine, a obnovljeni 2005. godine, posvećeni Vladanu Desnici, njegovu humanistički inspirativnom opusu te kulturi interkulturnog i transkulturnog dijaloga, svake godine završavaju u Kuli odavanjem počasti Vladanu Desnici i polaganjem vijenca na njegov grob u obiteljskoj crkvici sv. Đurđa u neposrednoj blizini Kule i odlaskom na "Klokotušu", do prošlog ljeta nepresušni izvor pitke, zdrave ravnokotarske vode koja održava svaki život u Kuli i oko Kule.

IV. Desničini susreti: jučer, danas i sutra. Kao što je već navedeno, jedan od ciljeva izložbe bila je i popularizacija Desničinih susreta. Nastojalo se pokazati da oni nisu samo znanstveni skup, već širi program koji obuhvaća raznovrsne inicijative i traje čitavu godinu. Jedna od njih svakako je i plodna izdavačka djelatnost, koja se, kao i sami skupovi, realizira pod okriljem Centra za komparativnohistorijske i interkulturne studije, ustrojbene jedinice Filozofskog fakulteta Sveučilišta u Zagrebu. Iako je u središtu izložbe uz skupove Desničini susreti bila istoimena biblioteka, sada već vizualno prepoznatljiva po svojim zbornicima radova, posjetitelji su mogli prelistati i ostala izdanja Centra. ${ }^{6}$

6 Centar za komparativnohistorijske i interkulturne studije ima četiri biblioteke: 1) Biblioteka Desničini susreti, 2) Biblioteka Dijalog s povodom, 3) Biblioteka Colloquia i 4) Programske knjižice Desničini susreti. Manja naklada izdanja Biblioteke Desničini susreti i komercijalno slaba "atraktivnost" izdanja obvezuju sve uključene da pronalaze nove načine dolaska do čitatelja i novih suradnika. Stoga su urednici, autori i nakladnici odlučili izdanja Centra 


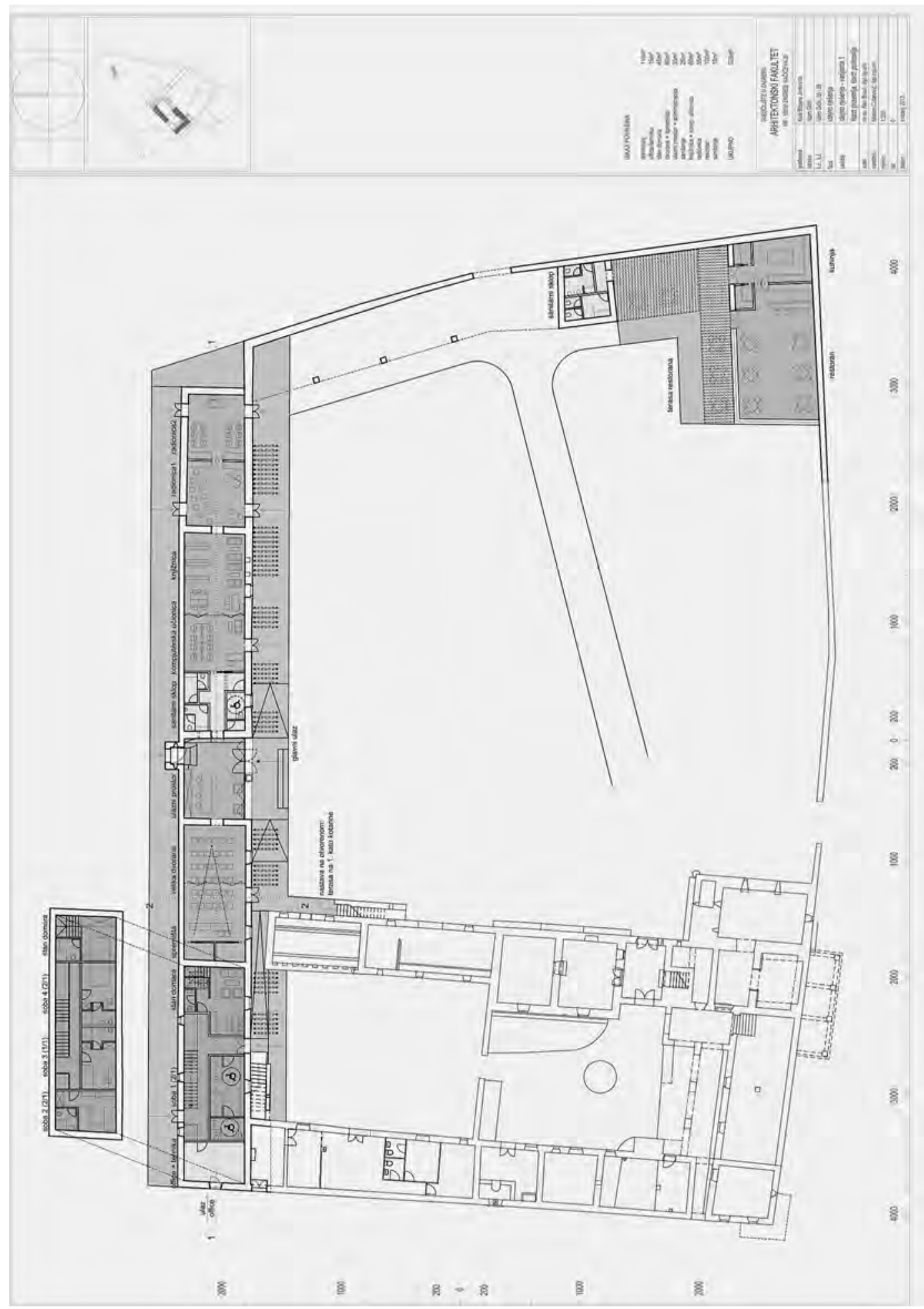

Sl. 10. Tlocrt jednog od idejnih rješenja Međunarodnoga sveučilišnog centra u dijelu Kule Jankovića. Autor: mr. sc. Alan Braun, Arhitektonski fakultet Sveučilišta u Zagrebu 
Da bi se shvatila vrijednost zbornika radova s Desničinih susreta - kojih je do 2013. godine objavljeno pet - neophodno je uzeti u obzir i programske knjižice Desničinih susreta. One se objavljuju kao posebna serija od 2009. godine. Između programske knjižice i zbornika kao "krune" jednogodišnjeg ciklusa dug je put, a u njemu se odražava i cjelogodišnji život Desničinih susreta. Iako se dijaloška kultura Desničinih susreta manifestira kroz raspravu, ova su dva izdanja često i "katalizator" rasprava, a ne samo njihov finalni proizvod. Ona ujedno i svjedoče o početnoj i završnoj fazi godišnjeg ritma Desničinih susreta.

Unatoč tomu što su opsegom bile mnogo skromnije od ostalih izdanja Centra, već su i prve programske knjižice Desničinih susreta imale vrlo veliku radnu težinu. Prvo, u njima se objavljuje pozivno pismo, koje je pak rezultat rasprava i usuglašavanja članova Pripremnog odbora. Svrha je programskih knjižica upoznati javnost s detaljnim programom rada $D e-$ sničnih susreta. Stoga se u njima uz pozivno pismo objavljuju i sažetci priopćenja te biobibliografski podatci o sudionicima. Međutim, njihova je druga važna zadaća i ta da nastoje potaknuti sudionike skupa, a i zainteresirane promatrače, da što je moguće jasnije artikuliraju odnos prema temama, a potom i moguće istraživačke hipoteze. Time se već i prije samog skupa pokušava osigurati što je moguće viša razina dijaloške kulture. Programske knjižice uvijek su jednim svojim dijelom posvećene i Vladanu Desnici i nastoje u njegovu opusu identificirati antologijske fragmente koji su poticajni za temu Desničinih susreta.

Druga faza cjelogodišnjeg programa Desničini susreti znanstveni su skupovi koji se od 2006. godine kontinuirano održavaju redovito koncem onoga rujanskog tjedna u kojemu je rođendan Vladana Desnice. Na samome skupu najvažnije je da priopćenja budu što konciznija, što jasnije problemski artikulirana i da se u načelu o svakome može kritički raspravljati. U prilog uspješnosti takva pristupa govori činjenica da sadržajne rasprave nakon svake sesije ili nakon nekoliko tematskih blokova često apsorbiraju više vremena nego sama priopćenja.

Iako uspjeh ovih prvih dviju faza može biti dovoljno jamstvo za uspješan zbornik, potrebno je još mnogo rada prije nego tekstovi budu spremni za tisak u obliku znanstvenih radova jer zbornici Desničini susreti nisu samo kompilacija različitih tekstova ili, pak, puko komentiranje neke teme. Naprotiv. Autori članaka svoja priopćenja često korigiraju i nadopunjavaju upravo zbog ili upravo zahvaljujući raspravama na Desničinim susretima. Mnogobrojni dogovori urednika i autora, a 2011. i 2012. i po dvoje recenzenata za svaki tekst, svjedoče o namjeri urednika da se stvore kritički što je moguće profiliranija izdanja. Ujednačenost i stvaranje prepoznatljive serije nastoji se postići kako vizualno tako i sadržajno te korištenjem inovativnih pristupa i metoda. ${ }^{7}$ Bio je to dovoljan razlog da jedna izložbena cjelina bude posvećena i Desničinim susretima.

učiniti svima dostupnima. Integralne verzije mogu se preuzeti na projektnim stranicama jednim klikom na naslov ili naslovnicu izdanja: http://kula-jankovica.unizg.hr/hr/desnicini-susreti/izdanja-centra/.

7 Osim zbornika radova s Desničinih susreta Biblioteka Desničini susreti uključuje i tri monografije, a i dalje je otvorena za knjige koje problematiziraju kulturna i civilizacijska višegraničja u komparatističkom ozračju. Riječ je o studiji Ivana Basića Od domus episcopi do Kule Jankovića. Prostorni razvoj Kule Stojana Jankovića u Islamu Grčkom, zatim zborniku radova nastalih kao rezultat istraživačke terenske nastave urednica Milane Černelić i Marijete Rajković Iveta Zapisi iz gornjih Ravnih kotara. Etnološki, povijesni i muzeološki prilozi o Islamu Latinskom, Islamu Grčkom, Kašiću i Podgradini te prijevodu knjige Hannesa Granditsa Obitelj i socijalne promjene u hrvatskim selima (18. - 20. stoljeće), interdisciplinarnoj komparatističkoj studiji slučaja sela Bobovac i Lekenik. 


\section{THE ExHIBITION: \\ Vladan Desnica and The Desnica MeEtings The Zadar Public Library, September i8-28 2013}

The text provides a short overview of the exhibition dedicated to Vladan Desnica and The Desnica Meetings, held in the Zadar Public Library between the 18th and the 28th of September 2013, as part of the international symposium entitled The Desnica Meetings 2013: An Intellectual Today. The exhibition was divided into four thematic units: 1. Vladan Desnica as a citizen of Zadar, 2. Vladan Desnica in Islam Grčki, 3. The Janković Castle in Islam Grčki: the vitality of the heritage and 4. The Desnica Meetings: yesterday, today and tomorrow. The primary goal of the exhibition was to educate the visitors from Zadar about Vladan Desnica as their fellow citizen and a co-inheritor of the Jankovic Castle, the cultural monument in the vicinity of Zadar. The secondary goal was to promote The Desnica Meetings, scholarly gatherings dedicated to the memory of Vladan Desnica. The organizers of the exhibition wanted to inform the visitors about the previous accomplishments of The Desnica Meetings and to encourage interest in engaging more actively with that program. They also provided information regarding the progress of the restoration of the Janković Castle in Islam Grčki, made possible by the financial and moral support of the Ministry of Culture of the Republic of Croatia. The visitors were informed about the concrete plans for its revitalization, most notably with the International University Centre project.

The exhibition was organized by the Centre for Comparative History and Intercultural Studies of the Faculty of Humanities and Social Sciences at the University of Zagreb and its program The Desnica Meetings and by the Association for the Renewal and the Revitalization of the Janković Castle - Bridges in cooperation with the Zadar Public Library and the Zadar Public Archives. The exhibition was co-authored by Professor Drago Roksandić (PhD) and Ivana Cvijović Javorina (PhD student), in cooperation with Uroš Desnica (PhD) and Olga Škarić (MA), while the exhibition panels were designed by Ana Pojatina.

Keywords: exhibition, Vladan Desnica, Desnica Meetings, Stojan Janković Castle, Islam Grčki (Croatia), Zadar (Croatia) 